\title{
潰瘍性大腸炎術後の回腸囊炎に 上部消化管病変を合併した一例
}

岡野 荘 ${ }^{1) *}$, 石沢 千尋 ${ }^{2}$, 酒匂美奈子 ${ }^{1)}$

吉村 直樹1), 阿部 佳子'3), 高添 正和 ${ }^{1)}$

要旨 : 症例は 34 歳女性, 27 歳時に全大腸炎型の潰瘍性大腸炎を発症した. 内科的治療抵抗 例として 29 歳時に全大腸摘出術および回腸囊肛門管吻合術を施行された.

術後 5 年目である, 34 歳時に上腹部痛および嘔気にて入院となり, 上部および下部消化 管内視鏡検査にて潰瘍性大腸炎の上部消化管病変抒よび回腸囊炎を認めた.メサラジン(ペ ンタサ $\left.{ }^{\circledR}\right)$ の粉砕投与およびメトロニダゾールの投与にて病状は改善し，退院となった．

潰瘍性大腸炎の術後に上腹部症状が出現した場合は潰瘍性大腸炎の上部消化管病変の存 在も考慮する必要があり，示唆に富む一例であったため報告する．

〔Key Words〕潰瘍性大腸炎, 上部消化管病変

\section{緒 言}

潰瘍性大腸炎 (以下 UC) は原則, 大腸に病変を 認める疾患であるが, 稀に胃・十二指腸・小腸領 域にも UC 様の病変が出現するという報告もあ る $^{1) 2}$.

今回, 胃・十二指腸領域に UC 様の病変を合併 した術後 UCの一例を経験したので報告する.

\section{症例}

症例 : 34 歳女性

主訴 : 嘔気・上腹部痛

既往歴：特記すべきことなし

生活歴：機会飲酒 喫煙歴なし

現病歴：2009 年 (27 歳時) に血便・下痢が増悪 し, 近医を受診.下部消化管内視鏡検査 (以下 $\mathrm{CS}$ ) にて全大腸炎型の UC の診断となった. 同年当院 紹介となり，タクロリムスと血球成分除去療法に て寛解導入できたが, 1 年後に再燃した. シクロス ポリン持続静注療法, インフリキシマブ療法にて 寛解導入できたが，以後も再燃を繰り返し，2011 年（29 歳時）に内科治療抵抗性であったため, 2 期分割にて大腸全摘術 + 回腸囊肛門管吻合術を施

\footnotetext{
${ }^{1)} \mathrm{JCHO}$ 東京山手メディカルセンター 炎症性腸疾患内科, ${ }^{2)} \mathrm{JCHO}$ 東京山手メディカルセンター 内科,

${ }^{3)} \mathrm{JCHO}$ 東京山手メディカルセンター 病理診断科

*Corresponding author: okano-soh@yamate.jcho.go.jp
}

行した。手術標本の組織学的所見は粘膜下層に UL-II の浅い潰瘍性病変を全大腸に認めるも, 肉 芽腫形成はなく潰瘍性大腸炎に矛盾しない所見で あった。

術後 3 年間は整腸剂のみで経過良好であった が, 2015 年, 術後 4 年目 (33 歳時) に排便回数が 増加し, CSにて回腸豪炎の診断となった。 ステロ イド注腸にて回腸豪炎は改善したが, 2016 年, 術 後 5 年目 (34 歳時) に嘔気・上腹部痛が出現, 排 便回数の増悪を認めたため, 精査加療目的で入院 となった。

入院時現症 : 体温 $37.2^{\circ} \mathrm{C}$, 脈拍 $82 /$ 分 - 整, 血圧 $102 / 72 \mathrm{mmHg}$, 眼瞼結膜貧血なし, 眼球結膜黄疸 なし, 腹部は平坦で上腹部圧痛認めるも筋性防御 なし，正中に人工肛門閉鎖後の瘏痕を認める.

排便回数 10 行/日 水様便〜軟便 血便なし.

臨床検査成績（Table 1) : 白血球, 血沈および $\mathrm{CRP}$ の上昇と高度の脱水症による $\mathrm{Hb}$ の高值を 認めた。

便培養 : 有意な病原菌の検出はなし

経過：入院後, 絶食・補液・ファモチジン 40 $\mathrm{mg} /$ 日・ドンペリドン $30 \mathrm{mg} /$ 日を開始した。第 3 病日にCS $($ Fig. 1) 施行, 回腸囊炎の再燃を認め, メトロニダゾール $500 \mathrm{mg} /$ 日, 整腸薬, メサラジン 坐剤を追加した。しかし，嘔気が持続するため, 第 5 病日に上部消化管内視鏡検査（以下 EGD） 
Table 1 Laboratory data on admission

\begin{tabular}{|c|c|c|c|c|c|}
\hline \multicolumn{3}{|c|}{ Hematology } & \multirow[b]{2}{*}{ Amy } & \multirow[b]{2}{*}{59} & \multirow[b]{2}{*}{ IU/I } \\
\hline WBC & 13.9 & $10^{3} / \mu l$ & & & \\
\hline RBC & 667 & $10^{4} / \mu l$ & BUN & 10 & $\mathrm{mg} / \mathrm{dL}$ \\
\hline $\mathrm{Hgb}$ & 18 & $\mathrm{~g} / \mathrm{dl}$ & Cre & 0.7 & $\mathrm{mg} / \mathrm{dL}$ \\
\hline $\mathrm{Ht}$ & 51.6 & $\%$ & UA & 5.9 & $\mathrm{mg} / \mathrm{dL}$ \\
\hline Plt & 68.7 & $10^{4} / \mu \mathrm{I}$ & $\mathrm{Na}$ & 130 & $\mathrm{mEq} / \mathrm{I}$ \\
\hline \multicolumn{3}{|c|}{ Biochemistry } & $\mathrm{K}$ & 3.8 & $\mathrm{mEq} / \mathrm{I}$ \\
\hline TP & 8.3 & $g / d l$ & $\mathrm{Cl}$ & 96 & $\mathrm{mEq} / \mathrm{I}$ \\
\hline Alb & 3.6 & $g / d l$ & CRP & 7.1 & $\mathrm{mg} / \mathrm{dL}$ \\
\hline T-Bil & 0.5 & $\mathrm{mg} / \mathrm{dL}$ & & & \\
\hline AST & 23 & IU/I & $\operatorname{ESR}(1 \mathrm{~h})$ & 29 & $\mathrm{~mm}$ \\
\hline ALT & 10 & $\mathrm{IU} / \mathrm{I}$ & & & \\
\hline LDH & 531 & $\mathrm{IU} / \mathrm{I}$ & & & \\
\hline ChE & 271 & $\mathrm{IU} / \mathrm{I}$ & & & \\
\hline ALP & 525 & $\mathrm{IU} / \mathrm{I}$ & & & \\
\hline$\gamma-\mathrm{GTP}$ & 68 & $\mathrm{IU} / \mathrm{I}$ & & & \\
\hline
\end{tabular}

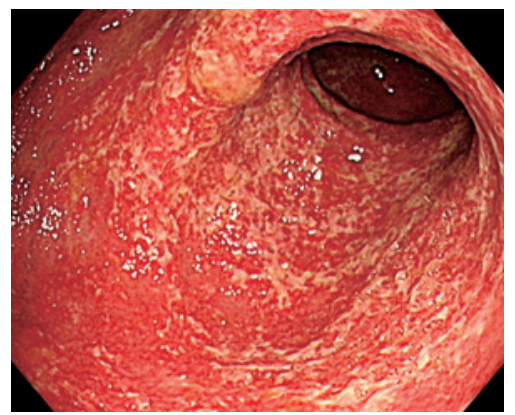

Fig. 1 Erosions and redness were diffusely detected in Jpouch

（Fig. 2）を施行したところ胃および十二指腸に UC 様の病変を認めた。病理所見（Fig. 3) では, 粘膜固有層樑層にリンパ球および形質細胞からな る炎症細胞の浸潤を認めた。 また, 迅速ウレアー ゼテストおよびH.pylori 抗体は院性であった。 H2blocker 投与下で H.pylori 陰性であり, かつ UC 様の内視鏡所見を新たに認めたため, UCの上部 消化管病変と診断し，メサラジンの粉砕投与を開 始した。第 8 病日に小腸病変の有無の精査のため 小腸造影施行したが, 潰瘍病変は認めなかった。 第 9 病日には嘔気・腹痛症状は改善し, 食事摂取 も可能となり, 排便回数も 6 行/日程度まで改善し たため, 第 11 病日に退院となった。 その後, メサ ラジンの粉砕投与と坐剂, 整腸薬にて再燃なく寛 解維持している.

\section{考 察}

今回, 術後 5 年目に回腸囊炎に UC の胃十二指 腸病変を合併した症例を経験した。

$\mathrm{UC}$ の胃十二指腸病変の報告は, $4.7 \%{ }^{3}$ から

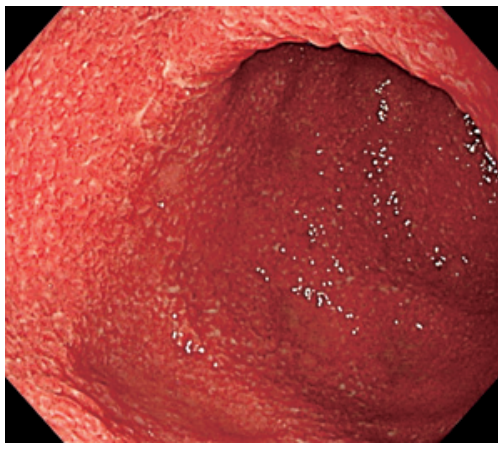

Fig. 2 Stomach and a duodenum showed redness and erosion similar to ulcerative colitis

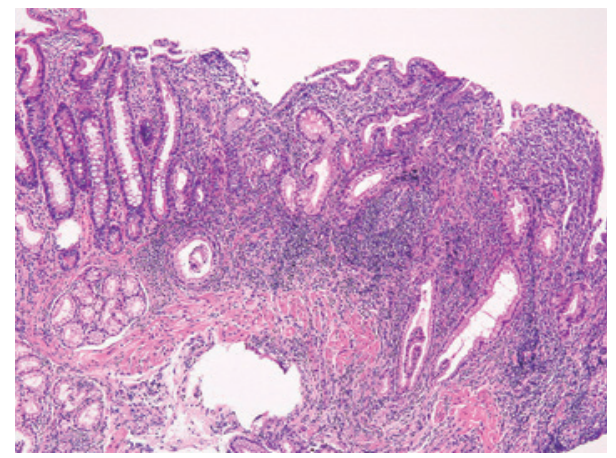

Fig. 3 Lympho-plasmacytic infiltration observed in the deep pat of lamina propria

$7.6 \%{ }^{4)}$ と幅があるが，その多くは全大腸炎型また は，大腸全摘後の報告である，本症例も全大腸炎 型 UC の大腸全摘後であった.

上部消化管病変の出現までの期間は報告により 差があるが, 久部ら ${ }^{3)}$ は 322 例中 15 例の検討で平 均罹病期間が 4.7 年であり, 術後平均 5.8 年目と報 告している. 本症例では発症後 7 年目, 術後 4 年 目に診断されている。しかし, UCの上部消化管病 変の診断まで EGD は施行されておらず，実際の 発症時期は不明であり, 診断時より以前に臨床症 状を伴わない軽微な病変が存在していた可能性も 否定できない.

渡辺ら ${ }^{5)}$ はC の上部消化管病変は病理学的に は陰窩底部の形質細胞浸潤，陰窩底部と粘膜筋板 との乘離, 陰窩密度の減少は特異性が高いと報告 している。 また, 制酸薬が無効であり,メサラジ ンやステロイドなどが有効であるという報告が多 い.これらはUC と同様に自己免疫疾患としての 
要素が病変形成に関与していることを示唆してい る. そのため, 一定の診断基準はないが, 渡辺ら 5 ) が報告している上記の病理所見や制酸薬が無効で あり，メサラジンやステロイドが効果を示すこと はUC の上部消化管病変を診断する上で有用であ ると考えられる。本症例も粘膜固有層媣層に形質 細胞浸潤を認めており, H2blocker は効果なく, メ サラジンの粉砕投与が著効している.

$\mathrm{UC} の$ 上部消化管病変の報告は最近増えてお り, 今後明確な診断基準および治療方法の確立が 必要である.

回腸豪炎は報告により差があるが, 術後 10 年で $50 \%$ 程度出現する ${ }^{6)}$. また, 回腸囊炎のリスクファ クターとしては全大腸炎型, 腸管外合併症, 非契 煙者, p-ANCA 陽性, NSAIDs の使用などが報告 されている. 回腸囊炎は抗菌薬のみで一過性に改 善するものが多いが, 一部は難治化し, 免疫調節 薬の投与が有効な症例がある。これは, 回腸囊炎 がUC 同様の自己免疫的な要素にて発症すること を示唆している.UCの上部消化管病変との関連
性について今後精査が望まれる.

\section{III 結 語}

上腹部痛や嘔気を有する術後 UC 症例では, UC の上部消化管病変も念頭において精查する必要が ある。

\section{文 献}

1) Terashima S, Hoshino Y, Kanazaki N, et al : Ulcerative duodenitis accompanying ulcerative colitis. J ClinGastroenterol 32(2) : 172-175, 2001

2 ) Rubenstein J, Sherif A, Appelman H, et al : Ulcerative colitis associated enteritis:is ulcerative colitis always confined to the colon? J Clin Gastroenterol 38(1) : 46-51, 2004

3 ) 久部高司, 松井敏幸, 宮岡正喜, 他：潰瘍性大腸炎に関連し た胃十二指腸病変の診断と臨床経過：回腸囊炎との関連性. 日本消化器内視鏡学会雑誌 $54: 2269-2277,2012$

4) Hori K, Ileuchi H, Nakano H, et al: Gastroduodenitis associated with ulcerative colitis. J Gastroenterol 43 : 193-201 2008

5 ）渡辺和彦：潰瘍性大腸炎に随伴する十二指腸病変の病理学 的特徵の検討. 123(5) : 232-241, 200

6 ) Oresland T, Bemelman WA, et al : European evidence based consensus on surgery for ulcerative colitis. J Crohns and Colitis $9: 4-15,2015$

\title{
A case of pouchitis and gastroduodenal lesion associated with $\mathrm{UC}$ after proctocolectomy
}

\author{
Soh Okano ${ }^{1 *}$, Chihiro Ishizawa ${ }^{2)}$, Minako Sako \\ Naoki Yoshimura $^{1)}$, Keiko Abe ${ }^{3)}$, Masakazu Takazoe ${ }^{1)}$
}

The case is of a 34-year-old female, who developed pan-ulcerative colitis at the age of 27 years. At the age of 29 years, because the patient was resistant to medical therapy, a total colectomy and ileal pouchanal canal anastomosis were performed.

At the age of 34 years, five years post-surgery, the patient was admitted to the hospital for upper abdominal pain and nausea. On performing upper and lower gastrointestinal endoscopy, upper gastrointestinal tract lesions of UC and pouchitis were detected. Upon administration of crushed 5ASA and metronidazole, the symptoms improved and the patient was discharged.

The reported case is a highly suggestive case indicating that upon post-UC surgery upper abdominal symptoms, the possibility of upper gastrointestinal lesions should be considered.

\footnotetext{
${ }^{1)}$ Department of Internal Medcine Division of IBD, Japan Community Health care Organization Tokyo Yamate Medical Center, ${ }^{2)}$ Department of Internal Medcine, Japan Community Health care Organization Tokyo Yamate Medical Center, ${ }^{3}$ Department of Pathology, Japan Community Health care Organization Tokyo Yamate Medical Center

*Corresponding author: okano-soh@yamate.jcho.go.jp
} 